\title{
Wiktor Trybka
}

Uniwersytet Zielonogórski

w.trybka@wpa.uz.zgora.pl

\section{Status administracyjnoprawny przedsiębiorcy wobec władczej ingerencji organu administracji publicznej - wybrane zagadnienia}

\author{
The Administrative and Legal Status of the Entrepreneur \\ in the Face of the Governmental Authority's Interference - \\ Selected Issues
}

\section{STRESZCZENIE}

Status administracyjnoprawny przedsiębiorcy w polskim porządku prawnym wyznaczony jest przez przepisy prawa administracyjnego materialnego i procesowego. Podstawową formą działania administracji publicznej, za pomocą której kreowany jest status administracyjnoprawny przedsiębiorcy, jest decyzja administracyjna. Na mocy aktu administracyjnego podmiotom, które prowadzą działalność gospodarczą, są przyznawane uprawnienia oraz nakładane są na nie obowiązki. Inny jest skutek prawny niewykonania przez przedsiębiorcę uprawnienia, a inny - niewykonania obowiązku. Brak realizacji obowiązku aktualizuje po stronie organów państwowych kompetencje do zastosowania wobec adresata aktu administracyjnego środków przymusu w ramach postępowania egzekucyjnego.

Słowa kluczowe: prawo administracyjne; akt administracyjny; Kodeks postępowania administracyjnego; organ administracji publicznej; Konstytucja

\section{WSTĘP}

Celem niniejszego opracowania jest wskazanie, jakie instytucje prawne służą władczej ingerencji w sytuację administracyjnoprawną przedsiębiorcy wykonującego przyznane uprawnienie na podstawie koncesji, a także wieloaspektowa analiza postępowania dotyczącego oceny realizacji przyznanego uprawnienia prawnego przez jednostkę. W ramach przywołanego postępowania można wyróżnić nastę- 
pujące płaszczyzny: 1) aspekt przedmiotowy i podmiotowy postępowania, 2) jego cechy istotne, 3) przesłanki warunkujące możliwość jego przeprowadzenia, 4) formę ingerencji i jej skutki prawne.

\section{ZASADA WOLNOŚCI DZIAŁALNOŚCI GOSPODARCZEJ A GRANICE TRWAŁOŚCI UPRAWNIENIA ADMINISTRACYJNOPRAWNEGO}

Analizując treść zasady wolności działalności gospodarczej, ochrony praw nabytych oraz trwałości ostatecznych decyzji administracyjnych, nasuwa się pytanie o granice wolności wykonywania przez przedsiębiorcę uprawnień gospodarczych wynikających z treści koncesji. Udzielenie na nie odpowiedzi wymaga nie tylko odniesienia się do tego, czy zasada wolności gospodarczej jest bezwzględnie obowiązująca, ale również do przedstawienia jej treści.

Wolność gospodarcza jest publicznym prawem podmiotowym ${ }^{1}$, stanowi filar społecznej gospodarki rynkowej oraz podstawę polskiego ustroju gospodarczego. Ujmowanie wolności gospodarczej jako prawa podmiotowego w płaszczyźnie teoretycznej ma tę zaletę, że spojrzenie przez jej pryzmat umożliwia jednolitą ocenę sytuacji prawnej wszystkich podmiotów, którym swoboda ta przysługuje ${ }^{2}$. Treścią wolności gospodarczej jest prawo do podejmowania, prowadzenia i zakończenia działalności gospodarczej w dowolnie wybranych formach prawnych ${ }^{3}$. W swoim orzecznictwie Trybunał Konstytucyjny zwrócił także uwagę na to, że:

[...] wolność wykonywania określonego rodzaju działalności gospodarczej mieści w sobie niewątpliwie zarówno aspekt ,ilościowy”, związany ze swobodą określania intensywności prowadzenia działalności, jak i ,jakościowy”, przez który rozumieć można swobodę określenia zakresu prowadzonej działalności (terytorialnego, personalnego, rzeczowego) ${ }^{4}$.

Akty prawa powszechnie obowiązującego przesądzają o tym, co jest treścią zasady wolności gospodarczej i jakie są jej granices. W związku z obowiązywaniem zasady wolności gospodarczej prawodawca skierował do organów władzy państwowej określone obowiązki, do których zalicza się: tworzenie materialnych

\footnotetext{
1 Wyrok TK z dnia 26 marca 2007 r., K 29/06, OTK-A 2007, nr 3, poz. 30.

2 A. Walaszek-Pyzioł, Swoboda działalności gospodarczej, Kraków 2004, s. 12-13.

3 Eadem, Wybrane problemy prawne dotyczace swobody działalności gospodarczej i jej zakresu przedmiotowego, [w:] Księga jubileuszowa Profesora Stanisława Jędrzejewskiego, red. W. Szwajdler, H. Nowicki, Toruń 2009, s. 512-513.

4 Wyrok TK z dnia 7 czerwca 2005 r., K 23/04, OTK-A 2005, nr 6, poz. 62.

5 A. Żurawik, Zasada wolności gospodarczej i jej ograniczenia, [w:] System Prawa Administracyjnego, t. 8A: Publiczne prawo gospodarcze, red. R. Hauser, Z. Niewiadomski, A. Wróbel, Warszawa 2013, s. 451.
} 
warunków sprzyjających realizacji wolności gospodarczej; zakaz wydawania aktów sprzecznych z zasadą wolności gospodarczej; obowiązek rozstrzygania wątpliwości na podstawie domniemania prawnego swobody działalności gospodarczej (in dubio pro libertate); zakaz rozszerzającej interpretacji wyjątków od zasady wolności gospodarczej ${ }^{6}$. Każdy zainteresowany podmiot prawa może podejmować wszelkie działania, których celem jest realizacja przyznanej mu wolności gospodarczej, chyba że są one sprzeczne z obowiązującymi przepisami prawa, zasadami uczciwej konkurencji, dobrych obyczajów oraz słusznych interesów konsumentów ${ }^{7}$. Wszelkie ograniczenia wolności gospodarczej muszą się znaleźć w ustawie ${ }^{8}$. S. Biernat ma rację, stwierdzając, że nakaz wyłączności ustawy, jako przesłanka wprowadzania ograniczeń wolności gospodarczej, stanowi klasyczny składnik demokratycznego państwa prawnego i łączy się z nakazem odpowiedniej szczegółowości i kompletności unormowań ustawowych bez zamieszczania norm blankietowych ${ }^{9}$. Ograniczeń zasady wolności gospodarczej nie można domniemywać, gdyż muszą być one jasno sprecyzowane w obowiązujących aktach prawnych ${ }^{10}$.

Ingerowanie przez organ, który wydał koncesję, w sytuację przedsiębiorcy w związku z oceną realizacji aktu administracyjnego należy zaliczyć do katalogu form ograniczeń wolności gospodarczej. Ingerencja władcza w wykonanie przyznanego w drodze aktu administracyjnego uprawnienia przez przedsiębiorcę stanowi ograniczenie wolności gospodarczej. Źródłem wspomnianego ograniczenia są ustawy, które w treści zawierają przepisy prawa administracyjnego materialnego, a także ustawa procesowa regulująca postępowania administracyjne. Należy zgodzić się ze stwierdzeniem, że „strona jest władna rozporządzać swoimi prawami, i to nie tylko przez wystąpienie $\mathrm{z}$ wnioskiem w sprawie autorytatywnej konkretyzacji prawa w drodze decyzji, lecz również może nimi rozporządzać po ich konkretyzacji, a więc przy wykonaniu decyzji" ${ }^{11}$. Nie można zmusić strony do skorzystania z uprawnienia ${ }^{12}$. Nie oznacza to, że jednostka może wykonywać przyznane jej uprawnienie w sposób dowolny. Jest ona zobowiązana czynić to zgodnie z prawem. W związku z tym ustawodawca nałożył na organ administracji publicznej obowią-

6 S. Biernat, Podejmowanie i prowadzenie działalności gospodarczej-wolność gospodarcza de lege lata i de lege ferenda, „Przegląd Prawa Handlowego” 1994, nr 9, s. 10.

7 K. Strzyczkowski, Konstytucyjna zasada społecznej gospodarki rynkowej jako podstawa tworzenia i stosowania prawa, [w:] Zasady ustroju społecznego i gospodarczego w procesie stosowania konstytucji, red. C. Kosikowski, Warszawa 2005, s. 21.

8 M. Szydło, Wolność działalności gospodarczej jako prawo podstawowe, Bydgoszcz-Wrocław 2011, s. 105-106.

9 S. Biernat, op. cit., s. 10.

10 A. Żurawik, op. cit., s. 453.

11 B. Adamiak, Kontrola organu administracji publicznej wykonania przez stronę decyzji administracyjnej, [w:] B. Adamiak, J. Borkowski, Postępowanie administracyjne i sadowoadministracyjne, Warszawa 2012, s. 338.

12 L. Klat-Wertelecka, Egzekucja administracyjna w praktyce, Gdańsk 2013, s. 13. 
zek czuwania nad wykonaniem decyzji administracyjnych. Trzeba mieć jednak przy tym na uwadze, że przepisy prawa administracyjnego materialnego mają znaczenie nie tylko w stadium podjęcia decyzji, ale też w trakcie jej wykonywania. Realizacja prawa obywateli do drogi administracyjnej polega nie tylko na ukształtowaniu jego pozycji prawnej przez wydanie określonej decyzji administracyjnej, ale również, a nawet przede wszystkim, na wykonaniu tej decyzji ${ }^{13}$.

\section{MATERIALNOPRAWNE COFNIĘCIE UPRAWNIENIA NA PODSTAWIE PRZEPISÓW SZCZEGÓLNYCH}

Instytucja materialnoprawna cofnięcia uprawnienia została unormowana w art. 163 Kodeksu postępowania administracyjnego ${ }^{14}$, który stanowi, że „organ administracji publicznej może uchylić lub zmienić decyzję, na mocy której strona nabyła prawo, także w innych przypadkach oraz na innych zasadach niż określone w niniejszym rozdziale, o ile przewidują to przepisy szczególne". Stanowi ona instrument kontroli prawidłowości wykonania przez strony decyzji administracyjnej i korzystania z praw z nich płynących ${ }^{15}$. W orzecznictwie Naczelny Sąd Administracyjny wskazuje, że praktyczne skorzystanie z instytucji materialnoprawnej cofnięcia uprawnienia wymaga, po pierwsze, jednoznacznego stwierdzenia, że adresat aktu administracyjnego nabył na jego podstawie uprawnienie, a po drugie, sprawdzenia, czy istnieje przepis prawa administracyjnego materialnego dający podstawę do wzruszenia mocy obowiązującej decyzji oraz wreszcie zbadania, czy w istniejącym stanie faktycznym i prawnym ma zastosowanie tryb postępowania przewidziany w przepisie art. 163 k.p.a. ${ }^{16}$ Wydanie decyzji wyłącznie na podstawie art. 163 k.p.a. stanowi przesłankę jej uchylenia przez sąd administracyjny ${ }^{17}$. Postępowanie w przedmiocie cofnięcia lub zmiany zakresu aktu administracyjnego należy prowadzić tylko w stosunku do decyzji ostatecznych. Rację ma J. Borkowski, pisząc, że:

[...] przy braku w art. 163 k.p.a. wskazania wprost, że odesłanie dotyczy tylko decyzji ostatecznych [...] wydaje się, że nabycie prawa powinno być wiązane z decyzją ostateczną, ponieważ w innym przypadku wzruszenie decyzji z mocy przepisów, do których odsyła się

${ }_{13}$ W. Taras, Egzekucja administracyjna a metody działania administracji publicznej, [w:] System egzekucji administracyjnej, red. J. Niczyporuk, S. Fundowicz, J. Radwanowicz, Warszawa 2004, s. 62.

${ }^{14}$ Ustawa z dnia 14 czerwca 1960 r. - Kodeks postępowania administracyjnego (t.j. Dz.U. z 2017 r., poz. 1257 z późn. zm.), dalej jako: k.p.a.

15 J. Borkowski, Zmiana i uchylenie ostatecznych decyzji administracyjnych, Warszawa 1967, s. $167-168$.

16 Postanowienie NSA we Wrocławiu z dnia 10 września 1993 r., SA/Wr 1156/93, Legalis.

17 J. Borkowski, Artykut 162, [w:] B. Adamiak, J. Borkowski, op. cit., s. 702. 
w art. 163 k.p.a., stałoby się konkurencyjne w stosunku do postępowania odwoławczego, co naruszałoby zasadę dwuinstancyjności statuowaną w art. 15 k.p.a. ${ }^{18}$

W orzecznictwie sądów administracyjnych można spotkać się ze stanowiskiem, że przepis art. 163 k.p.a. jest swoistym zwornikiem pomiędzy procesową instytucją „uchylenia decyzji” a materialnoprawną instytucją ,,cofnięcia uprawnienia”, której następstwem jest usunięcie z obrotu prawnego decyzji uprawniającej ${ }^{19}$. Zgodzić należy się z tym, że w sytuacji kolizji trybów nadzwyczajnych, możliwych do zastosowania w odniesieniu do decyzji ostatecznej, tryb szczególny, o którym wzmiankuje art. 163 k.p.a., musi ustąpić trybom uregulowanym w rozdziałach 12 i 13 k.p.a. ${ }^{20}$ K. Klonowski zauważa, że „na mocy przepisu art. 163 k.p.a. dochodzi do weryfikacji pierwotnej konkretyzacji i organ albo dokonuje ponownej konkretyzacji (zmiana), albo znosi ją (uchylenie)"21. W przypadku decyzji zmieniającej można przyjąć, skoro tworzy ona nową sytuację prawną podmiotu w zakresie nabytego przez niego na podstawie innej decyzji konstytutywnej uprawnienia, że również ona jest decyzją konstytutywną ${ }^{22}$. Odnosząc się do decyzji uchylającej, NSA wskazał, że uchylenie decyzji w trybie szczególnym może wywoływać skutek prawny w zależności od stanu faktycznego i prawnego danej sprawy bądź od momentu wydania, bądź od daty wskazanej w jej rozstrzygnięciu. Na tej podstawie także tej decyzji należy przypisać charakter aktu konstytutywnego ${ }^{23}$. Organem właściwym do wydania w I instancji decyzji w trybie wskazanym w przepisach szczególnych i w art. 163 k.p.a. jest z reguły organ właściwy w I instancji dla załatwienia sprawy, której rozstrzygnięcie ma być zmieniane albo uchylane $^{24}$. Przepisem szczególnym, który może stanowić podstawę uchylenia lub zmiany decyzji, może być wyłącznie przepis rangi ustawowej oraz przepisy aktów prawnych wydanych na podstawie delegacji wykonawczej zawartej w ustawach ${ }^{25}$. Takim przepisem szczegółowym jest m.in. art. 58 ustawy z dnia 2 lipca 2004 r. o swobodzie działalności gospodarczej ${ }^{26}$.

${ }_{18}$ Ibidem, s. 702-703. Por. również: wyrok WSA w Kielcach z dnia 9 czerwca 2014 r., II SA/ Ke 415/14, LEX nr 1479328.

19 Wyrok NSA we Wrocławiu z dnia 16 maja 1991 r., SA/Wr 371/91, OSP 1991, nr 11, poz. 268; wyrok WSA w Kielcach z dnia 29 czerwca 2016 r., I SA/Ke 482/16, LEX nr 2150699; wyrok WSA w Łodzi z dnia 8 marca 2013 r., III SA/Łd 1111/12, LEX nr 1303718; wyrok WSA w Warszawie z dnia 4 marca 2011 r., II SA/Wa 1531/10, LEX nr 1097118.

${ }^{20}$ Szerzej: W. Chróścielewski, A. Korzeniowska, Glosa do wyroku NSA z dnia 31.7.2002 r., II SA/Gd 441/00, „Orzecznictwo Sądów Polskich” 2004, z. 2, poz. 1.

${ }^{21}$ K. Klonowski, Artykut 163, [w:] Kodeks postepowania administracyjnego, red. H. Knysiak-Molczyk, Warszawa 2016.

${ }^{22}$ Wyrok WSA w Łodzi z dnia 12 września 2009 r., II SA/Łd 449/12, LEX nr 1241629.

23 Wyrok NSA z dnia 7 grudnia 2011 r., I OSK 1148/11, LEX nr 1149121.

${ }^{24}$ K. Klonowski, op. cit.

25 Wyrok NSA w Warszawie z dnia 28 maja 1991 r., II SA 369/91, ONSA 1991, nr 3-4, poz. 63.

26 T.j. Dz.U. z 2017 r., poz. 2168 z późn. zm., dalej jako: u.s.d.g. 


\section{STRONA PODMIOTOWA POSTĘPOWANIA W SPRAWIE WŁADCZEJ INGERENCJI W SYTUACJĘ ADMINISTRACYJNOPRAWNĄ PRZEDSIĘBIORCY}

Cecha charakterystyczną władczej ingerencji w sytuację administracyjnoprawną przedsiębiorcy jest nierównorzędność podmiotów, z tym że zawsze jednym z podmiotów jest organ administracji publicznej, którego rola polega na tym, że najpierw ocenia realizację wykonania uprawnienia przez przedsiębiorcę, a następnie (w razie potrzeby) przeprowadza postępowanie administracyjne, którego wynik jest uzależniony od wcześniejszej oceny. Między przedsiębiorcą a organem zostaje nawiązany na powrót stosunek procesowy. Zarówno nawiązanie, jak i ustanie stosunku procesowego zawsze wiąże się z określeniem wzajemnej relacji między podmiotami tego stosunku w płaszczyźnie podmiotowej i przedmiotowej ${ }^{27}$. Nierównorzędna pozycja prawna tego stosunku przejawia się w tym, że to do organu administracji zawsze należy ostatnie słowo, gdyż to on objawia swoją wolę jako ostatni. Tak wyrażona wola ma charakter decydujący, podczas gdy oświadczenie woli jednostki $\mathrm{w}$ istocie pełni funkcję pomocniczą ${ }^{28}$. Prawa i obowiązki przysługujące organom administracji publicznej zazwyczaj nie są dostępne dla adresatów rozstrzygnięć tych organów. Przedsiębiorca, który otrzymuje rozstrzygnięcie organu, musi się mu podporządkować pod rygorem poniesienia przewidzianych prawem sankcji. Podmiot znajdujący się na zewnątrz ustroju administracji publicznej swoim działaniem nie może uregulować niczyjej sytuacji prawnej aktem władczym ${ }^{29}$. Organ administracji publicznej w opisanej relacji jest wyposażony w kompetencje do wyznaczenia, oceny i ewentualnie wymuszenia właściwego zachowania się po stronie przedsiębiorcy ${ }^{30}$. Nie jest natomiast uprawniony do odbioru uprawnień przeznaczonych dla obywatela.

Organ administracji publicznej, oceniając realizację uprawnienia administracyjnoprawnego, zazwyczaj czyni to w stosunku do osoby, która pierwotnie nabyła uprawnienie. Należy jednak pamiętać, że w ramach następstwa materialnego może dojść do przeniesienia uprawnień i obowiązków określonych w decyzji administracyjnej. Przejęcie przez podmiot praw i obowiązków drugiego podmiotu na ogół

27 J. Starościak, Stosunek administracyjnoprawny, [w:] System Prawa Administracyjnego, red. T. Rabska, J. Łętowski, t. 3, Wrocław-Warszawa-Kraków-Gdańsk 1978, s. 21.

${ }_{28}$ J. Borkowski, Decyzja administracyjna, Warszawa 1970, s. 41 i n.; idem, Pojęcie władztwa administracyjnego, „Acta Universitatis Wratislaviensis. Przegląd Prawa i Administracji” 1972, s. 46 i n.; idem, Określenie prawa administracji państwowej, „Zeszyty Naukowe Akademii Spraw Wewnętrznych" 1974, s. 168.

29 J. Filipek, O podmiotowości administracyjnoprawnej, „Państwo i Prawo” 1961, z. 2, s. 199. Szerzej: idem, Elementy strukturalne norm prawa administracyjnego, Warszawa-Kraków 1982, s. 30.

30 J. Zimmermann, Polska jurysdykcja administracyjna, Wrocław 2000, s. 434. 
nie oznacza biernej roli administracji ${ }^{31}$. Następstwo materialne uprawnienia lub obowiązku ma miejsce w chwili przejścia uprawnień i obowiązków, ale z jednym ważnym zastrzeżeniem - że dotyczy podmiotu, który znajduje się na zewnątrz administracji publicznej, a nie organu, który władczo skonkretyzował uprawnienie lub obowiązek. K.M. Ziemski wskazuje, że w prawie administracyjnym bez wyraźnej podstawy prawnej nie może mieć miejsca zmiana elementu podmiotowego, jakim jest adresat decyzji ${ }^{32}$. Podobnie E. Szczygłowska podkreśla, że „uprawnienia i obowiązki istniejące po stronie podmiotu zewnętrznego względem administracji zasadniczo powstają nie dlatego, że ktoś inny posiadał (te same) uprawnienia czy obowiązki, ale przede wszystkim dlatego, że tak stanowi przepis prawa lub rozstrzygnięcie organu administracji publicznej dokonane na podstawie tego przepisu"33. K.M. Ziemski zauważa, że w prawie administracyjnym materialnym można wyróżnić dwie formy następstwa - na podstawie decyzji administracyjnej (gdzie następca prawny wchodzi w oznaczone uprawnienia i obowiązki wynikające z decyzji) oraz z mocy prawa (gdzie następca prawny wchodzi we wszystkie uprawnienia i obowiązki lub wybraną ich grupę) $)^{34}$. E. Szczygłowska zauważa, że:

[...] pojęciem sukcesji administracyjnoprawnej uniwersalnej trzeba objąć przypadki, w których jeden podmiot, zewnętrzny względem administracji, na podstawie jednego zdarzenia prawnego przejmuje uprawnienia i obowiązki administracyjnoprawne innego podmiotu, wchodząc w ogół (lub przynajmniej dającą się wyodrębnić część) stosunków administracyjnoprawnych (zewnętrznych), łączących ten podmiot z organem administracji publicznej35.

\section{STRONA PRZEDMIOTOWA POSTĘPOWANIA W SPRAWIE WŁADCZEJ INGERENCJI W SYTUACJE ADMINISTRACYJNOPRAWNĄ PRZEDSIĘBIORCY}

Organ, ingerując $\mathrm{w}$ sytuację administracyjnoprawną przedsiębiorcy, de facto ocenia realizację przez przedsiębiorcę wcześniej przyznanego mu uprawnienia. W nauce prawa administracyjnego nie ma jednolitych poglądów na rozumienie „uprawnienia administracyjnoprawnego”. W obowiązującym prawie brak jest definicji legalnej tego pojęcia. Jest to termin języka prawnego i prawniczego. Źró-

${ }_{31}$ M. Miemiec, Nastęstwo prawne w prawie administracyjnym, „Przegląd Prawa i Administracji” 1990, t. 26, s. 31.

32 K.M. Ziemski, Sukcesja praw i obowiązków publiczno-prawnych, „Zeszyty Naukowe Sądownictwa Administracyjnego" 2009, nr 1, s. 9.

${ }^{33}$ E. Szczygłowska, Sukcesja uprawnień i obowiązków administracyjnych, Warszawa 2009, s. 40.

${ }^{34}$ K.M. Ziemski, op. cit., s. 10-11.

35 E. Szczygłowska, op. cit., s. 98. 
dłem uprawnienia administracyjnoprawnego są przepisy prawa administracyjnego materialnego i procesowego. D.R. Kijowski słusznie zauważa, że:

[...] spośród około tysiąca obowiązujących w Polsce ustaw w niemal każdej z nich możemy spotkać przepisy, które stwarzają szanse i gwarantują jednostce możliwość uzyskania od państwa lub od innych podmiotów sprawujących w nim władzę publiczną działań zapewniających jej korzystną, podlegającą ochronie prawnej (wobec tego państwa, jego organów, a także innych podmiotów prawa), sytuację ${ }^{36}$.

Doktryna prawa administracyjnego niechętnie posługuje się pojęciem ,uprawnienie" ${ }^{37}$. Przedstawiciele teorii i filozofii prawa definiują na gruncie językowym uprawnienie następująco. Po pierwsze, ,X jest uprawniony do zachowania się Z na podstawie normy N". Uprawnienie stanowi tutaj pochodną takich zwrotów, jak: wolność, powinność, prawo do... Po drugie, ,zachowanie się podmiotu X stanowi realizację uprawnienia ze względu na normę $\mathrm{N}^{38}$. S. Wronkowska określa uprawnienie jako ,sytuację, w której ze względu na określoną normę prawną określonym podmiotom nakazane jest zrealizować na rzecz innej osoby zachowanie się polegające na pozytywnym działaniu na rzecz tej innej osoby, bądź na zaniechaniu podjęcia określonych działań”39. Z. Ziembiński łączy pojęcie uprawnienia z:

[...] sytuacją podmiotu, któremu jakieś zachowanie nie jest zakazane przez daną normę czy też nie jest zakazane przez żadną normę danego systemu prawnego lub jest określeniem sytuacji kogoś, wobec którego jakiś inny podmiot jest zobowiązany do określonego zachowania się, zachowania korzystnego, a więc świadczenia polegającego na odpowiednim działaniu czy zaniechaniu oddziaływania na sprawy podmiotu uprawnionego, wreszcie określa uprawnienie jako sytuację jakiegoś podmiotu, mającego kompetencję do dokonania jakiejś czynności doniosłej prawnie z tym skutkiem, iż przez jej dokonanie zostanie ustanowiony obowiązek prawny jakiegoś podmiotu ${ }^{40}$.

W. Dawidowicz nie definiuje pojęcia uprawnienia, ale wskazuje na jego rodzaje. Autor ten wyróżnia następujące typy uprawnień:

${ }^{36}$ D.R. Kijowski, Uprawnienia administracyjnoprawne, [w:] System Prawa Administracyjnego, t. 7: Prawo administracyjne materialne, red. R. Hauser, Z. Niewiadomski, A. Wróbel, Warszawa 2012, s. 240.

${ }^{37}$ S. Ciarkowski, Plan podziału a zasada sukcesji uniwersalnej częściowej - wybrane zagadnienia szczegółowe, „Prawo Spółek” 2003, nr 12, s. 12.

${ }_{38}$ W. Lang, Pojęcia prawne i prawnicze, [w:] Teoria państwa i prawa, red. W. Lang, J. Wróblewski, S. Zawadzki, Warszawa 1980, s. 325.

39 S. Wronkowska, Analiza pojęcia prawa podmiotowego, Poznań 1973, s. 33.

${ }^{40}$ Z. Ziembiński, Problemy podstawowe prawoznawstwa, Warszawa 1980, s. 352-353. 
- uprawnienie w postaci „możności prawnej” żądania stosowania normy prawa administracyjnego w celu uzyskania określonego pozwolenia (np. pozwolenia na wykonanie czynności objętej zakazem względnym) lub uprawnienia (np. uprawnienia do zajęcia cudzej nieruchomości),

- uprawnienie w postaci „wolności od obowiązku” (np. ustawowe zwolnienia od obowiązku ponoszenia świadczeń na różne cele),

- uprawnienie w postaci „prawa” stanowiącego korelat nałożonego obowiązku (np. ustawowe prawo do wynagrodzenia i odszkodowanie służące osobom obciążonym obowiązkiem świadczeń na cele publiczne),

- uprawnienie w postaci „sfery wolności prawnie chronionej”, powstałej z wyłączeniem spod zakazu względnego ${ }^{41}$.

Klasyfikację uprawnień administracyjnoprawnych przedstawił J. Borkowski, zaliczając do nich:

[...] po pierwsze, prawa nabyte, których treścią jest zezwolenie na podjęcie działania przez podmiot uprawniony. Aktywność podmiotu uprawnionego będzie rozpoczynała się po otrzymaniu stosownej decyzji administracyjnej. Po drugie, uprawnienie może przybrać postać stwierdzenia, że na danym podmiocie nie ciąży obowiązek. Zwolnienie z obowiązku może nastąpić w dwóch odrębnych sytuacjach: na mocy aktu administracyjnego lub władczej ingerencji organu w sytuację prawną określonego podmiotu. Do trzeciej grupy uprawnień zaliczyć możemy prawo polegające na domaganiu się świadczeń od innych podmiotów lub państwa ${ }^{42}$.

\section{PRZESŁANKI MATERIALNE OCENY REALIZACJI UPRAWNIENIA PRZEZ PRZEDSIĘBIORCĘ NA PRZYKŁADZIE USTAWY O SWOBODZIE DZIAŁALNOŚCI GOSPODARCZEJ}

Cofnięcie lub zmiana koncesji na podstawie art. 58 u.s.d.g. jest możliwe tylko wtedy, gdy właściwy organ administracji publicznej łącznie zastosuje przepis art. 58 u.s.d.g. z przepisem art. 163 k.p.a. Ustawa o swobodzie działalności gospodarczej reguluje wyłącznie przesłanki materialne cofnięcia lub zmiany koncesji. Kwestie procesowe zostały unormowane w przepisach regulujących postępowanie administracyjne. Przepis art. 58 u.s.d.g. normuje dwie formy pozbawienia adresata koncesji jego uprawnień: obligatoryjną i fakultatywną ${ }^{43}$. W tym przypadku forma cofnięcia uprawnienia jest ściśle uzależniona od przesłanki materialnej. Cofnięcie lub zmiana zakresu koncesji może mieć miejsce tylko w przypadku wystąpienia jednej z przesłanek wskazanych enumeratywnie w art. 58 u.s.d.g., które winny być

\footnotetext{
${ }^{41}$ W. Dawidowicz, Prawo administracyjne, Warszawa 1987, s. 26-27.

42 J. Borkowski, Zmiana i uchylenie ostatecznych decyzji..., s. 17-18.

${ }^{43}$ M. Zdyb, Działalność gospodarcza i publiczne prawo gospodarcze, Kraków 2001, s. 59.
} 
interpretowane w sposób ścisły ${ }^{44}$. Zakaz wykładni rozszerzającej wynika z potrzeby poszanowania unormowanej w art. 16 k.p.a. zasady trwałości ostatecznych decyzji administracyjnych.

Organ obligatoryjnie cofa koncesję w przypadku, gdy wystąpią następujące przesłanki: wydano prawomocne orzeczenie zakazujące przedsiębiorcy wykonywania działalności gospodarczej objętej koncesją; przedsiębiorca nie podjął w wyznaczonym terminie działalności objętej koncesją, mimo wezwania organu koncesyjnego, lub trwale zaprzestał wykonywania działalności gospodarczej objętej koncesją. Organ koncesyjny fakultatywnie cofa koncesję wtedy, gdy: rażąco narusza warunki określone w koncesji lub inne warunki wykonywania koncesjonowanej działalności gospodarczej, określone przepisami prawa; w wyznaczonym terminie nie usunął stanu faktycznego lub prawnego niezgodnego $\mathrm{z}$ warunkami określonymi w koncesji lub z przepisami regulującymi działalność gospodarczą objętą koncesją. Ponadto organ koncesyjny może cofnąć koncesję albo zmienić jej zakres ze względu na zagrożenie obronności lub bezpieczeństwa państwa lub bezpieczeństwa obywateli, a także jeżeli wydano decyzję o stwierdzeniu niedopuszczalności wykonywania praw z udziałów albo akcji przedsiębiorcy na podstawie przepisów ustawy z dnia 24 lipca 2015 r. o kontroli niektórych inwestycji ${ }^{45}$ albo też w razie ogłoszenia upadłości przedsiębiorcy (art. 58 ust. 3 u.s.d.g.). Wykładnia językowa przepisu art. 58 ust. 3 u.s.d.g. prowadzi do wniosku, że:

[...] wskazany przepis wprowadza uznanie administracyjne organu koncesyjnego w zakresie oceny, czy z uwagi na zagrożenie obronności i bezpieczeństwa państwa lub bezpieczeństwa obywateli istnieje konieczność cofnięcia koncesji. Należy wskazać, że ocena wystąpienia istnienia zagrożenia tych dóbr należy do organu koncesyjnego. Natomiast ogłoszenie upadłości przedsiębiorcy jest faktem obiektywnym ${ }^{46}$.

Ustawa o swobodzie działalności gospodarczej nie przewiduje instytucji wygaśnięcia koncesji z powodu zaprzestania wykonywania działalności gospodarczej. Dlatego w takiej sytuacji należy cofnąć koncesję, ponieważ staje się ona bezprzedmiotowa ${ }^{47}$.

Cofnięcie lub zmiana koncesji rodzi określone skutki prawne dla koncesjonariusza. Należy się zgodzić z C. Kosikowskim, iż:

${ }^{44}$ S. Biernat, A. Wasilewski, Ustawa o działalności gospodarczej, Kraków 1997, s. 351.

45 T.j. Dz.U. z 2016 r., poz. 980 z późn. zm.

${ }^{46}$ M. Sieradzka, Art. 58, [w:] M. Zdyb, M. Sieradzka, Ustawa o swobodzie działalności gospodarczej. Komentarz, Warszawa 2013, s. 458.

47 Wyrok NSA z dnia 12 listopada 1993 r., II SA 2000-2001/92, ONSA 1995, nr 1, poz. 13. 
[...] cofnięcie koncesji powoduje, że koncesjonariusz zostaje pozbawiony prawa do wykonywania działalności objętej koncesją. Cofnięcie koncesji nie likwiduje wykonywanej działalności gospodarczej, lecz nakazuje jej zaprzestanie, co nie musi z kolei wiązać się z potrzebą likwidacji prawnej przedsiębiorcy i z koniecznością wykreślenia osoby prawnej $\mathrm{z}$ rejestru, chyba że byt prawny tej osoby był związany wyłącznie z działalnością gospodarczą objętą koncesjonowaniem $^{48}$.

Przepis art. 58 ust. 1 u.s.d.g. nie ma charakteru sankcyjnego, lecz stanowi o pozbawieniu koncesji przedsiębiorcy, który nie może prowadzić działalności gospodarczej lub jej nie prowadzi. Koncesja więc nie jest mu potrzebna. Może być natomiast potrzebna innemu przedsiębiorcy, zwłaszcza gdy liczba koncesji jest ograniczona $^{49}$. Odwrotnie jest w przypadku przepisu art. 58 ust. 2 u.s.d.g., który ma charakter sankcji administracyjnej ${ }^{50}$. Sankcja administracyjna jest stosowana wobec adresata aktu wtedy, gdy nie usunął on w wyznaczonym przez organ koncesyjny terminie uchybień w stanie faktycznym lub prawnym, ocenianym z punktu widzenia warunków określonych w koncesji lub przepisach prawnych regulujących działalność gospodarczą koncesjonowaną ${ }^{51}$.

Cofnięcie koncesji powinno stanowić środek stosowany przez organ koncesyjny w ostatniej kolejności. Ponadto na wybór jednego z wyżej wymienionych środków, stosowanych przez organ koncesyjny na podstawie art. 58 ust. 2 u.s.d.g., powinna mieć wpływ także okoliczność, który z przypadków wymienionych w tym przepisie zaistniał, rodząc po stronie tego organu obowiązek podjęcia stosownej decyzji. Uzasadnienie wydanej decyzji powinno wykazywać powody wyboru takiego, a nie innego środka ${ }^{52}$.

\section{PRAWOMOCNE ORZECZENIE ZAKAZUJĄCE PRZEDSIĘBIORCY WYKONYWANIA DZIAŁALNOŚCI GOSPODARCZEJ OBJĘTEJ KONCESJĄ}

Jedną z podstaw wydania orzeczenia zakazującego przedsiębiorcy wykonywanie działalności gospodarczej objętej koncesją jest art. $41 \S 2$ Kodeksu karnego ${ }^{53}$, który stanowi, że sąd może orzec zakaz prowadzenia określonej działalności gospodarczej

${ }^{48}$ C. Kosikowski, Art. 58, [w:] Ustawa o swobodzie działalności gospodarczej. Komentarz, Warszawa 2013.

49 Ibidem.

${ }^{50}$ K. Strzyczkowski, Prawo gospodarcze publiczne, Warszawa 2007, s. 236.

51 Ibidem.

52 Wyrok Sądu Ochrony Konkurencji i Konsumenta z dnia 4 lipca 2013 r., XVII AmE 89/11, LEX nr 1728663; wyrok NSA z dnia 27 marca 1991 r., II SA 205/91, ONSA 1992, nr 3-4, poz. 60.

${ }^{53}$ Ustawa z dnia 6 czerwca 1997 r. - Kodeks karny (t.j. Dz.U. z 2017 r., poz. 2207 z późn. zm.). 
w razie skazania za przestępstwo popełnione w związku z prowadzeniem takiej działalności, jeżeli dalsze jej prowadzenie zagraża istotnym dobrom chronionym prawem. Obowiązek cofnięcia koncesji powstaje dopiero w dniu uprawomocnienia się orzeczenia zakazującego przedsiębiorcy wykonywanie działalności gospodarczej ${ }^{54}$.

Sąd Apelacyjny w Warszawie zwrócił uwagę na to, że w wypadku spółek osobowych do cofnięcia koncesji na zasadzie art. 58 ust. 1 pkt 1 u.s.d.g. wystarczy stwierdzenie istnienia prawomocnego orzeczenia zakazującego wykonywania działalności wobec jednego ze wspólników. Bez znaczenia pozostaje w takiej sytuacji fakt, że inny ze wspólników nie został skazany i może prowadzić sprawy spółki. Nie chodzi tutaj o to, czy wspólnik spółki jawnej dokonuje czynu będącego podstawą cofnięcia koncesji w imieniu spółki, gdyż popełniając czyn, wspólnik nie musi reprezentować spółki, chociaż oczywiście jest możliwa taka sytuacja, gdy np. fałszuje dokumenty, na podstawie których koncesjonariusz jest zobowiązany do zapłaty stosownego podatku. Jedynym wyznacznikiem jest to, czy popełniony czyn, za który następuje prawomocne skazanie, ma związek z przedmiotem działalności gospodarczej określonej ustawą ${ }^{55}$.

\section{PRZEDSIĘBIORCA NIE PODJĄŁ W WYZNACZONYM TERMINIE DZIAŁALNOŚCI OBJĘTEJ KONCESJĄ}

Drugim przypadkiem uzasadniającym obowiązkowe cofnięcie koncesji jest brak podjęcia przez przedsiębiorcę w wyznaczonym terminie działalności objętej koncesją, mimo wezwania organu koncesyjnego, lub trwałe zaprzestanie wykonywania działalności gospodarczej objętej koncesją ${ }^{56}$. Konieczność cofnięcia koncesji w przypadkach określonych w art. 58 ust. 1 pkt 2 u.s.d.g. należy uzasadniać brakiem podjęcia lub kontynuacji wykonywania działalności, która jest potrzebna ze względów gospodarczych lub społecznych, przy jednoczesnej niemożliwości udzielenia takiej samej koncesji innemu podmiotowi. $Z$ brzmienia art. 58 ust. 1 pkt 2 u.s.d.g. wynika również, że nie jest potrzebne uprzednie wezwanie przedsiębiorcy przez organ koncesyjny do podjęcia na nowo trwale zaprzestanej działalności, co jest konieczne tylko w przypadku niepodejmowania przez przedsiębiorcę działalności objętej koncesją ${ }^{57}$. Określenie samego terminu rozpoczęcia działalności koncesjonowanej nie stanowi problemu, gdyż powinien on być wskazany w treści koncesji. K. Kohutek słusznie zauważa, że:

${ }^{54}$ K. Kohutek, Art. 58, [w:] M. Brożyna, M. Chudzik, J. Molis, S. Szuster, K. Kohutek, Swoboda działalności gospodarczej. Komentarz, Warszawa 2005.

${ }^{55}$ Wyrok SA w Warszawie z dnia 13 lipca 2016 r., VI ACa 774/15, LEX nr 2109267.

${ }^{56}$ Ibidem.

${ }^{57}$ Wyrok SA w Warszawie z dnia 19 lipca 2016 r., VI ACa 580/15, LEX nr 2112341. 
[...] wezwanie koncesjonariusza przez organ koncesyjny do podjęcia działalności, na którą udzielono koncesji, jest formalnym warunkiem wydania - w razie oczywistej bezskuteczności takiego wezwania, tj. dalszego braku podjęcia działalności przez przedsiębiorcę decyzji o cofnięciu koncesji. Ustawa nie przesądza, kiedy, tj. po upływie jakiego czasu od daty, w której powinno nastąpić rozpoczęcie wykonywania koncesjonowanej działalności, organ koncesyjny powinien wezwać przedsiębiorcę do podjęcia tej działalności. Ustawa nie przewiduje także, aby w treści tego wezwania organ koncesyjny wyznaczył termin na podjęcie działalności. Oznacza to, że po dokonaniu przedmiotowego wezwania przez organ koncesyjny przedsiębiorca, nadal niepodejmujący działalności gospodarczej, na którą uzyskał koncesję, będzie musiał się liczyć z tym, iż kolejnym środkiem podjętym przez organ koncesyjny będzie decyzja o cofnięciu tej koncesji ${ }^{58}$.

Prawodawca podkreśla, że cofnięcie koncesji jest możliwe, jeżeli przedsiębiorca trwale zaprzestanie wykonywania działalności gospodarczej. Oznacza to, że czasowe nieprowadzenie działalności koncesjonowanej nie jest podstawą do cofnięcia przyznanego uprawnienia administracyjnoprawnego. P. Wrześniewski zauważa, że:

[...] trwałe jest tylko takie zaprzestanie działalności, które nie rokuje nadziei na jej podjęcie w dającym się przewidzieć terminie. Organ powinien tutaj zachować daleko idącą ostrożność. Jego działanie podlega bowiem kontroli sądu administracyjnego. Trwałe zaprzestanie wykonywania działalności gospodarczej objętej koncesją może mieć miejsce mimo tego, że inną działalność przedsiębiorca cały czas prowadzi ${ }^{59}$.

Od trwałego zaprzestania wykonywania działalności gospodarczej należy odróżnić sytuację, w której zostaje ona zawieszona. Ustawodawca pozwala przedsiębiorcy na zawieszenie prowadzenia działalności gospodarczej - art. 14a u.s.d.g. stanowi, że przedsiębiorca niezatrudniający pracowników może zawiesić wykonywanie działalności gospodarczej na okres od 30 dni do 24 miesięcy. Zawieszenie działalności gospodarczej nie jest czasowym jej zaprzestaniem, ale jej ograniczeniem $^{60}$. Zawieszenie działalności gospodarczej, jak również wznowienie zawieszonej działalności gospodarczej, pociąga za sobą konsekwencje prawne, które odnoszą się do uprawnień i obowiązków przedsiębiorców, a także mają swój skutek dla innych podmiotów (Skarbu Państwa, gminy, ZUS, NFZ itp.) ${ }^{61}$.

\footnotetext{
${ }^{58}$ K. Kohutek, op. cit.

59 P. Wrześniewski, Ustawa o swobodzie działalności gospodarczej, Warszawa 2010, s. 152.

${ }^{60}$ Wyrok z dnia 17 czerwca 2011 r., II UK 377/2010, LEX nr 3057472.

${ }^{61}$ Szerzej: C. Kosikowski, op. cit.
} 


\section{RAŻĄCE NARUSZENIE WARUNKÓW OKREŚLONYCH W KONCESJI LUB INNYCH WARUNKÓW WYKONYWANIA KONCESJONOWANEJ DZIAŁALNOŚCI GOSPODARCZEJ}

Prawodawca posłużył się w art. 58 u.s.d.g. pojęciem „rażące naruszenie”, jednocześnie go nie definiując. W orzecznictwie podnosi się, że mamy do czynienia z rażącym naruszeniem wtedy, gdy działanie przedsiębiorcy korzystającego z uprawnień przyznanych na mocy koncesji cechuje się oczywistością wynikającą z pełnej świadomości naruszenia zasad, wysokim natężeniem złej woli, znacznym stopniem przekroczenia norm czy wielością niedozwolonych działańn ${ }^{62}$. O tym, czy w danym przypadku mamy do czynienia z rażącym naruszeniem warunków koncesji czy nie, zawsze decydują konkretne okoliczności danej sprawy ${ }^{63}$. Przed organami administracji publicznej i sądami stoi zadanie ustalenia w każdym przypadku, co należy uznać w danym stanie faktycznym za rażące naruszenie warunków określonych w koncesji lub innych warunków wykonywania koncesjonowanej działalności gospodarczej.

\section{PODSUMOWANIE}

Materialnoprawne cofnięcie uprawnienia jest instytucją prawną. Nie stanowi ono tylko i wyłącznie instytucji procesowej. Jej praktyczne zastosowanie wymaga współstosowania przepisów prawa administracyjnego materialnego i procesowego, co oznacza, że dopiero łączne spojrzenie na nie tworzy pełen kształt omawianej instytucji prawnej. Ponadto należy pamiętać, że podstawą prawną decyzji administracyjnej wydanej w wyniku przeprowadzenia postępowania w sprawie władczej ingerencji $\mathrm{w}$ sytuację administracyjnoprawną przedsiębiorcy są przepisy prawa administracyjnego procesowego i materialnego. Jest to decyzja rozstrzygająca sprawę co do istoty. Oznacza to, że jest to klasyczna decyzja merytoryczna organu administracji publicznej. Decyzja ta dokonuje zmiany w sytuacji prawnej podmiotu prowadzącego działalność gospodarczą. Jej treścią jest nie tylko pozbawienie wcześniej przyznanego prawa podmiotowego lub zmienienie jego zakresu, ale również jej efektem może być nałożenie na przedsiębiorcę różnego rodzaju obowiązków.

Uprawnienie do podjęcia i prowadzenia działalności gospodarczej powinno być trwałe. Jedną z podstaw ingerencji w moc obowiązującą decyzji na płaszczyźnie materialnej i formalnej jest przepis art. 163 k.p.a. współstosowany z przepisami prawa administracyjnego materialnego. Należy się zgodzić z M.A. Waligórskim, który wskazuje, że:

${ }^{62}$ Wyrok Sądu Ochrony Konkurencji i Konsumenta z dnia 5 stycznia 2017 r., XVII AmE 11/16, LEX nr 2275507; wyrok SA w Warszawie z dnia 2 lipca 2015 r., VI ACa 1196/14, LEX nr 1934380.

${ }_{63}$ Wyrok WSA w Łodzi z dnia 16 maja 2014 r., III SA/Ld 246/14. 
[...] cofnięcie lub zmiana koncesji łączy się z reguły $\mathrm{z}$ wkroczeniem w sferę nabytych przez koncesjonariusza praw. W demokratycznym państwie prawnym stabilność decyzji administracyjnych, tym bardziej koncesji, powinna być szczególnie chroniona jako składnik porządku prawnego oraz przejaw ochrony praw słusznie nabytych ${ }^{64}$.

Jednak ochrona praw słusznie nabytych w tym przypadku nie jest absolutna. Organ przyznający uprawnienia musi posiadać możliwość oceny realizacji decyzji administracyjnej. Organ administracji publicznej, decydując o tym, czy cofnąć lub zmienić zakres koncesji w oparciu o art. 58 u.s.d.g., powinien rozważyć wszystkie okoliczności wynikające ze stanu faktycznego i prawnego sprawy. Obowiązek organu w tym przypadku wynika expressis verbis z zasady proporcjonalności, którą należy uznać za jedną z zasad prawa administracyjnego ${ }^{65}$.

Postępowanie w przedmiocie cofnięcia lub zmiany zakresu koncesji jest klasycznym postępowaniem administracyjnym prowadzonym w I instancji, do którego zastosowanie mają przepisy k.p.a. Decyzja wydana w ramach tego postępowania jest decyzją wydaną w I instancji66. Jest to postępowanie odrębne w tym sensie, że nie stanowi kontynuacji postępowania o udzielenie koncesji ${ }^{67}$. Od decyzji nieostatecznej służy odwołanie, natomiast od decyzji ostatecznej - skarga do sądu administracyjnego. Skutkiem wydania decyzji administracyjnej w analizowanym postępowaniu może być, po pierwsze, pozostawienie wcześniej przyznanych uprawnień bez zmian, a po drugie, zmiana zakresu uprawnień i wreszcie ich całkowite pozbawienie. Rację ma M.A. Waligórski, wskazując, że:

[...] istotą instytucji materialnoprawnego cofnięcia uprawnienia jest uszczuplenie praw jednostki nabytych na podstawie aktu administracyjnego przyznającego dane uprawnienie. [...] ograniczenie uprawnienia jest cofnięciem uprawnienia w części i polega na wydaniu nowej decyzji zmieniającej wcześniejszą decyzję o wydaniu uprawnienia, przy czym podstawą takiej zmiany jest odpowiedni przepis szczególny ${ }^{68}$.

Władztwo administracyjne jest cechą konstytutywną postępowania, którego przedmiotem jest ocena realizacji przez przedsiębiorcę koncesji. Posługiwanie się w tym miejscu pojęciem ,władztwo administracyjne” jest daleko idącym uogól-

${ }^{64}$ M.A. Waligórski, Koncesje, zezwolenia i licencje w polskim administracyjnym prawie gospodarczym, Poznań 2012, s. 848.

65 Ibidem, s. 849.

${ }^{66}$ Uchwała SN (7) z dnia 15 grudnia 1984 r., III AZP 8/83, OSN - Izba Cywilna 1985, nr 10, poz. 143.

${ }^{67}$ Wyrok SA w Warszawie z dnia 11 kwietnia 2013 r., VI ACa 936/12, Legalis.

${ }^{68}$ M.A. Waligórski, op. cit., s. 849. 
nieniem, gdyż właściwie należy tutaj pisać o władztwie procesowym ${ }^{69}$. Władztwo w tym przypadku obejmuje ,umocowanie organu administracji publicznej do jednostronnego decydowania o treści rozstrzygnięcia administracyjnego; domniemanie legalności podjętego działania prawnego oraz zabezpieczenie odpowiedniego wykonania orzeczenia administracyjnego właściwą sankcją prawną"70.

\section{BIBLIOGRAFIA}

Adamiak B., Kontrola organu administracji publicznej wykonania przez stronę decyzji administracyjnej, [w:] B. Adamiak, J. Borkowski, Postepowanie administracyjne i sadowoadministracyjne, Warszawa 2012.

Adamiak B., Borkowski J., Kodeks postępowania administracyjnego. Komentarz, Warszawa 2012. Biernat S., Podejmowanie i prowadzenie działalności gospodarczej-wolność gospodarcza de lege lata $i$ de lege ferenda, „Przegląd Prawa Handlowego” 1994, nr 9.

Biernat S., Wasilewski A., Ustawa o działalności gospodarczej, Kraków 1997.

Borkowski J., Artykut 162, [w:] B. Adamiak, J. Borkowski, Postepowanie administracyjne i sądowoadministracyjne, Warszawa 2012.

Borkowski J., Decyzja administracyjna, Warszawa 1970.

Borkowski J., Określenie prawa administracji państwowej, „Zeszyty Naukowe Akademii Spraw Wewnętrznych" 1974.

Borkowski J., Pojęcie władztwa administracyjnego, „Acta Universitatis Wratislaviensis. Przegląd Prawa i Administracji” 1972.

Borkowski J., Zmiana i uchylenie ostatecznych decyzji administracyjnych, Warszawa 1967.

Chróścielewski W., Korzeniowska A., Glosa do wyroku NSA z dnia 31.7.2002 r., II SA/Gd 441/00, „Orzecznictwo Sądów Polskich” 2004, z. 2, poz. 1.

Ciarkowski S., Plan podziału a zasada sukcesji uniwersalnej częściowej - wybrane zagadnienia szczegółowe, „Prawo Spółek” 2003, nr 12.

Dawidowicz W., Prawo administracyjne, Warszawa 1987.

Filipek J., Elementy strukturalne norm prawa administracyjnego, Warszawa-Kraków 1982.

Filipek J., O podmiotowości administracyjnoprawnej, „Państwo i Prawo” 1961, z. 2.

Kiczka K., Wybrane praktyczne problemy administracyjnych aktów kwalifikujacych, [w:] Między tradycją a przyszłością w nauce prawa administracyjnego. Księga jubileuszowa dedykowana Profesorowi Janowi Bociowi, red. J. Supernat, Wrocław 2009.

Kijowski D.R., Uprawnienia administracyjnoprawne, [w:] System Prawa Administracyjnego, t. 7: Prawo administracyjne materialne, red. R. Hauser, Z. Niewiadomski, A. Wróbel, Warszawa 2012.

Klat-Wertelecka L., Egzekucja administracyjna w praktyce, Gdańsk 2013.

Klonowski K., Artykut 163, [w:] Kodeks postępowania administracyjnego, red. H. Knysiak-Molczyk, Warszawa 2016.

69 Szerzej: W. Trybka, Koncepcja władztwa procesowego, „Zeszyty Naukowe Sądownictwa Administracyjnego" 2017, nr 1, s. 65-75.

${ }^{70} \mathrm{~K}$. Kiczka, Wybrane praktyczne problemy administracyjnych aktów kwalifikujacych, [w:] Między tradycją a przyszłościa w nauce prawa administracyjnego. Księga jubileuszowa dedykowana Profesorowi Janowi Bociowi, red. J. Supernat, Wrocław 2009, s. 265. 
Kohutek K., Art. 58, [w:] M. Brożyna, M. Chudzik, J. Molis, S. Szuster, K. Kohutek, Swoboda działalności gospodarczej. Komentarz, Warszawa 2005.

Kosikowski C., Art. 58, [w:] Ustawa o swobodzie działalności gospodarczej. Komentarz, Warszawa 2013.

Lang W., Pojęcia prawne i prawnicze, [w:] Teoria państwa i prawa, red. W. Lang, J. Wróblewski, S. Zawadzki, Warszawa 1980.

Miemiec M., Nastęstwo prawne w prawie administracyjnym, „Przegląd Prawa i Administracji” 1990, t. 26.

Postanowienie NSA we Wrocławiu z dnia 10 września 1993 r., SA/Wr 1156/93, Legalis.

Sieradzka M., Art. 58, [w:] M. Zdyb, M. Sieradzka, Ustawa o swobodzie działalności gospodarczej. Komentarz, Warszawa 2013.

Starościak J., Stosunek administracyjnoprawny, [w:] System Prawa Administracyjnego, red. T. Rabska, J. Łętowski, t. 3, Wrocław-Warszawa-Kraków-Gdańsk 1978.

Strzyczkowski K., Konstytucyjna zasada społecznej gospodarki rynkowej jako podstawa tworzenia $i$ stosowania prawa, [w:] Zasady ustroju społecznego i gospodarczego w procesie stosowania konstytucji, red. C. Kosikowski, Warszawa 2005.

Strzyczkowski K., Prawo gospodarcze publiczne, Warszawa 2007.

Szczygłowska E., Sukcesja uprawnień i obowiązków administracyjnych, Warszawa 2009.

Szydło M., Wolność działalności gospodarczej jako prawo podstawowe, Bydgoszcz-Wrocław 2011.

Taras W., Egzekucja administracyjna a metody działania administracji publicznej, [w:] System egzekucji administracyjnej, red. J. Niczyporuk, S. Fundowicz, J. Radwanowicz, Warszawa 2004.

Trybka W., Koncepcja władztwa procesowego, „Zeszyty Naukowe Sądownictwa Administracyjnego” 2017, $\mathrm{nr} 1$.

Uchwała SN (7) z dnia 15 grudnia 1984 r., III AZP 8/83, OSN - Izba Cywilna 1985, nr 10, poz. 143.

Ustawa z dnia 14 czerwca 1960 r. - Kodeks postępowania administracyjnego (t.j. Dz.U. z 2017 r., poz. 1257 z późn. zm.).

Ustawa z dnia 6 czerwca 1997 r. - Kodeks karny (t.j. Dz.U. z 2017 r., poz. 2207 z późn. zm.).

Ustawa z dnia 2 lipca 2004 r. o swobodzie działalności gospodarczej (t.j. Dz.U. z 2017 r., poz. 2168 z późn. zm.).

Ustawa z dnia 24 lipca 2015 r. o kontroli niektórych inwestycji (t.j. Dz.U. z 2016 r., poz. 980 z późn. $\mathrm{zm}$.).

Walaszek-Pyzioł A., Swoboda działalności gospodarczej, Kraków 2004.

Walaszek-Pyzioł A., Wybrane problemy prawne dotyczace swobody działalności gospodarczej i jej zakresu przedmiotowego, [w:] Ksiega jubileuszowa Profesora Stanisława Jędrzejewskiego, red. W. Szwajdler, H. Nowicki, Toruń 2009.

Waligórski M.A., Koncesje, zezwolenia i licencje w polskim administracyjnym prawie gospodarczym, Poznań 2012.

Wronkowska S., Analiza pojęcia prawa podmiotowego, Poznań 1973.

Wrześniewski P., Ustawa o swobodzie działalności gospodarczej, Warszawa 2010.

Wyrok NSA z dnia 27 marca 1991 r., II SA 205/91, ONSA 1992, nr 3-4, poz. 60.

Wyrok NSA we Wrocławiu z dnia 16 maja 1991 r., SA/Wr 371/91, OSP 1991, nr 11, poz. 268.

Wyrok NSA w Warszawie z dnia 28 maja 1991 r., II SA 369/91, ONSA 1991, nr 3-4, poz. 63.

Wyrok NSA z dnia 12 listopada 1993 r., II SA 2000-2001/92, ONSA 1995, nr 1, poz. 13.

Wyrok NSA z dnia 7 grudnia 2011 r., I OSK 1148/11, LEX nr 1149121.

Wyrok SA w Warszawie z dnia 11 kwietnia 2013 r., VI ACa 936/12, Legalis.

Wyrok SA w Warszawie z dnia 2 lipca 2015 r., VI ACa 1196/14, LEX nr 1934380.

Wyrok SA w Warszawie z dnia 13 lipca 2016 r., VI ACa 774/15, LEX nr 2109267.

Wyrok SA w Warszawie z dnia 19 lipca 2016 r., VI ACa 580/15, LEX nr 2112341. 
Wyrok Sądu Ochrony Konkurencji i Konsumenta z dnia 4 lipca 2013 r., XVII AmE 89/11, LEX nr 1728663.

Wyrok Sądu Ochrony Konkurencji i Konsumenta z dnia 5 stycznia 2017 r., XVII AmE 11/16, LEX nr 2275507.

Wyrok SN z dnia 17 czerwca 2011 r., II UK 377/2010, LEX nr 3057472.

Wyrok TK z dnia 7 czerwca 2005 r., K 23/04, OTK-A 2005, nr 6, poz. 62.

Wyrok TK z dnia 26 marca 2007 r., K 29/06, OTK-A 2007, nr 3, poz. 30.

Wyrok WSA w Łodzi z dnia 12 września 2009 r., II SA/Łd 449/12, LEX nr 1241629.

Wyrok WSA w Warszawie z dnia 4 marca 2011 r., II SA/Wa 1531/10, LEX nr 1097118.

Wyrok WSA w Łodzi z dnia 8 marca 2013 r., III SA/Łd 1111/12, LEX nr 1303718.

Wyrok WSA w Łodzi z dnia 16 maja 2014 r., III SA/Łd 246/14.

Wyrok WSA w Kielcach z dnia 9 czerwca 2014 r., II SA/Ke 415/14, LEX nr 1479328.

Wyrok WSA w Kielcach z dnia 29 czerwca 2016 r., I SA/Ke 482/16, LEX nr 2150699.

Zdyb M., Działalność gospodarcza i publiczne prawo gospodarcze, Kraków 2001.

Ziembiński Z., Problemy podstawowe prawoznawstwa, Warszawa 1980.

Ziemski K.M., Sukcesja praw i obowiązków publiczno-prawnych, „Zeszyty Naukowe Sądownictwa Administracyjnego" 2009, $\mathrm{nr} 1$.

Zimmermann J., Polska jurysdykcja administracyjna, Wrocław 2000.

Żurawik A., Zasada wolności gospodarczej i jej ograniczenia, [w:] System Prawa Administracyjnego, t. 8A: Publiczne prawo gospodarcze, red. R. Hauser, Z. Niewiadomski, A. Wróbel, Warszawa 2013.

\section{SUMMARY}

The legal and administrative status of the entrepreneur in the Polish legal order is determined by the provisions of substantive and procedural administrative law. The basic form of operation of the public administration by means of which the administrative and legal status of entrepreneurs is created is the administrative decision. Under the administrative act, entrepreneurs are granted allowances and obligations. Another is the legal effect of non-compliance with the permission and another the obligation. No implementation of the obligation updates the authority's ability to apply to the addressee of the administrative measure coercive in the enforcement proceedings.

Keywords: administrative law; administrative act; Code of Administrative Procedure; public authority; Constitution 